\title{
Roles of Fungal Volatiles from Perspective of Distinct Lifestyles in Filamentous Fungi
}

\author{
Mohamed El-Agamy Farh and Junhyun Jeon (1D* \\ Department of Biotechnology, College of Life and Applied Sciences, Yeungnam University, Gyeongsan 38541, Korea \\ (Received on February 11, 2020; Revised on April 25, 2020; Accepted on April 27, 2020)
}

Volatile compounds (VOCs) are not only media for communication within a species but also effective tools for sender to manipulate behavior and physiology of receiver species. Although the influence of VOCs on the interactions among organisms is evident, types of VOCs and specific mechanisms through which VOCs work during such interactions are only beginning to become clear. Here, we review the fungal volatile compounds (FVOCs) and their impacts on different recipient organisms from perspective of distinct lifestyles of the filamentous fungi. Particularly, we discuss the possibility that different lifestyles are intimately associated with an ability to produce a repertoire of FVOCs in fungi. The FVOCs discussed here have been identified and analyzed as relevant signals under a range of experimental settings. However, mechanistic insight into how specific interactions are mediated by such FVOCs at the molecular levels, amidst complex community of microbes and plants, requires further testing. Experimental designs and advanced technologies that attempt to address this question will facilitate our understanding and applications of FVOCs to agriculture and ecosystem management.

Keywords : environmental VOCs, lifestyles, volatile compounds

\footnotetext{
*Corresponding author.

Phone) +82-53-810-3030, FAX) +82-53-810-4769

E-mail) jjeon@yu.ac.kr

ORCID

Junhyun Jeon

https://orcid.org/0000-0002-0617-4007

(c) This is an Open Access article distributed under the terms of the Creative Commons Attribution Non-Commercial License (http:// creativecommons.org/licenses/by-nc/4.0) which permits unrestricted noncommercial use, distribution, and reproduction in any medium, provided the original work is properly cited.
}

Articles can be freely viewed online at www.ppjonline.org.
Handling Editor : Jungkwan Lee

Biological complexity at the community level is built on specific interactions/communications between organisms. These interactions/communications are entwined with each other and held in balance through complex network underpinning property and behavior of community as a whole. Such interaction/communication is either intraspecific or inter-specific, and is mediated by a diverse array of molecules. Frequently, those molecules are volatiles and thus able to diffuse in space and time. One paradigmatic example of such chemical interaction/communication is one among ants. It is well established that ants use volatile compounds (VOCs) to identify nestmates, recognize the food sources, and recruit co-workers for expanding the colony size (Richard and Hunt, 2013). In fact, a list of such chemical interaction/communication is endless: Plants use VOCs to attract pollinators and seed disseminators, or to fend off herbivores and pathogens directly or indirectly by recruiting their natural predators (Das et al., 2013; De Vega et al., 2014; Holopainen and Blande, 2012; Ueda et al., 2012); VOCs are also used in establishing symbiotic relationships between plants and the belowground organisms (Schausberger et al., 2012; Wenke et al., 2010); Some moth species call their mate using VOCs as well. Despite ample examples of VOCs in nature, the subcellular actions of VOCs are poorly understood due to the labile nature, complexity, and diversity of VOCs (Kanchiswamy et al., 2015; Pichersky et al., 2006).

VOCs are key players not only in interactions between macro-organisms, but also in microbial interactions (Garbeva et al., 2014; Kai et al., 2016; Schmidt et al., 2015, 2016; Vespermann et al., 2007). It has long been known that some bacteria can give off VOCs that can promote plant growth and immunity, giving them the name, plant 
growth promoting rhizobacteria (Ryu et al., 2004). Recent works on bacterial volatiles also corroborate such plant growth promoting as well as anti-fungal effects of diverse bacterial volatiles (Vespermann et al., 2007). Over the last decade, fungal volatile compounds (FVOCs) gained a lot of attention from the agricultural research due to their promising bioactivities on the plant growth improvements and protection (Jalali et al., 2017; Naznin et al., 2013, 2014). A number of reviews have been dedicated to discussing individual FVOCs and their ecological and biotechnological impacts (Hung et al., 2015; Kaddes et al., 2019; Morath et al., 2012; Schalchli et al., 2016). However, it is clear that FVOCs and their ecological functions identified to date should be only the tip of the iceberg in terms of diversity and number of FVOCs that are present in nature. Considering that filamentous fungi exhibit different lifestylessaprophyte, pathogen, endophyte, and mutualist, which require many physiological and morphological adaptations, one interesting hypothesis would be correlation between lifestyles and types of FVOCs. Here we review the types of the known FVOCs and their potential functions with distinct lifestyles, and examined the possibility that FVOCs serve as a primer to establishing different ecological niches. In addition, we point out discrepancy between functions of FVOCs identified or inferred from experimental settings and functions of FVOCs in natural settings. Finally, we suggest approaches to address such discrepancy in experimental designs and further shed light on other future directions to explore more environmental roles of FVOCs.

\section{Roles of FVOCs from Lifestyle Perspective}

Saprophytic fungi. Saprophytes are the group of organisms that are fully incapable of feeding on living cells of other organisms but on the decaying organic matters that are available in their environment, in order to obtain essential nutrients for their growth. Saprophytic fungi comprise the largest group of fungi that live in either bulk or rhizosphere soil, and can survive on non-living matters such as fallen trees, cow feces, dead leaves, and even dead insects and animals. They acquire their nutrition by digesting these complicated dead matters into elementary substances using extracellular enzymes, and thus have a crucial ecological role in soil nutrition cycling (Baldrian and Valásková, 2008; Clegg and Mackean, 2000; Dinis et al., 2009; Hobbie et al., 1999; McMillan and Boynton, 1994; Mishra et al., 2011). Saprophytic fungi are also capable of producing plethora of secondary metabolites (Fox and Howlett, 2008), including volatiles exhibiting diverse biological effects. For example, Trichoderma and Phoma species produce aliphatic compounds, such as isobutyl alcohol, isopentyl alcohol, 2-methyl-propanol, 3-methylbutanal, 3-methyl-acetate, and aromatics such as sesquiterpenes, diterpenes, tetraterpenes and pyranones, which promote plant growth as indicated by increased biomass and chlorophyll content, compared to untreated plants. Furthermore, some of these molecules, in a dose-dependent manner, cause increase in root branching and number of root hairs, and enhance tolerance against biotic and abiotic stresses. Such plant protection is exerted either directly by antimicrobial activity against fungal pathogens or indirectly by enhancing plant immunity (Garnica-Vergara et al., 2016; Hung et al., 2013; Kottb et al., 2015; Lee et al., 2016; Naznin et al., 2013; Strobel, 2006). Trichoderma species produce low-molecular-weight compounds, including alcohols, ketones, alkanes, and furanes, which have varied antifungal activities (Stoppacher et al., 2010). Due to these countless bioprotective behaviors of Trichoderma species, they are mass-produced with different formulations for direct application to seed or cultivating soils targeting the population of economically important phytopathogens (Woo et al., 2014). Other than Trichoderma, there are many examples of soil-borne saprophytic fungi such as Cladosporium and Ampelomyces species that produce multifaceted FVOCs ( $\mathrm{Li}$ et al., 2019; Paul and Park, 2013; Woo et al., 2014). Other examples of saprophytes producing FVOCs with diverse biological activities are summarized in Table 1 . The ecological function of these diversely active FVOCs produced by saprophytes is still elusive. However, lifestyle of these groups of fungi could account for the potential function of these flying molecules. Saprobes are unable to invade living hosts and mainly depend on complicated non-living organic matters for procuring all required nutrients. This means that they should compete with millions of other microbes for common nutrient sources. Getting a competitive edge over nutrients can be achieved, on the one hand, by emission of FVOCs having antimicrobial activity around the hyphae of the producer, rendering its surroundings competitors-free. On the other hand, FVOCs with plant growth-promoting effects enhance plant growth, leading to increase in production of exudates, which in turn increase the availability of organic nutrients required for growth of saprophytes themselves (Fig. 1A).

Pathogenic fungi. Pathogenic fungi are those that acquire nutrients from either feeding on living host cells or by killing host cells. Different species of pathogenic fungi evolved distinct mode of life: some are strictly dependent on living host cells the whole life cycle (obligate parasites), some can live perfectly the majority of life cycle on dead 
Table 1. Fungi with different lifestyles and biological actions and their fungal volatile compounds attributed to their actions

\begin{tabular}{|c|c|c|c|c|}
\hline Lifestyle & Fungi & Actions & Volatile compounds & Reference \\
\hline \multirow[t]{9}{*}{ Saprophytic } & $\begin{array}{l}\text { Trichoderma asperel- } \\
\text { lum and T. atroviride }\end{array}$ & $\begin{array}{l}\text { Plant-growth promoting, } \\
\text { anti-fungal, induction of } \\
\text { systemic resistance }\end{array}$ & $\begin{array}{l}\text { 6-Pentyl-2H-pyran-2-one, 2-pentyl furan, } \\
\text { 2-n-heptylfuran, 3-octanone, 2-hepta- } \\
\text { none, 2-nonanone, 2-undecanone }\end{array}$ & $\begin{array}{l}\text { Stoppacher et al. (2010), } \\
\text { Kottb et al. (2015), Garnica- } \\
\text { Vergara et al. (2016) }\end{array}$ \\
\hline & $\begin{array}{l}\text { Trichoderma pseudo- } \\
\text { koningii and } T \text {. viride }\end{array}$ & Plant growth promotion & $\begin{array}{l}\text { Sesquiterpenes, diterpenes, and tetra- } \\
\text { terpenes, isobutyl alcohol, isopentyl } \\
\text { alcohol, 3-methylbutanal }\end{array}$ & $\begin{array}{l}\text { Hung et al. (2013), } \\
\text { Lee et al. (2016) }\end{array}$ \\
\hline & Phoma sp. & Plant-growth promoting & 2-Methyl propanol, 3-methyl-butanol & Naznin et al. (2013) \\
\hline & $\begin{array}{l}\text { Cladosporium clado- } \\
\text { sporioides }\end{array}$ & Plant-growth promoting & $\begin{array}{l}\alpha \text {-Pinene, }(-) \text {-trans-caryophyllene, } \\
\text { tetrahydro-2,2,5,5-tetramethylfuran, de- } \\
\text { hydroaromadendrene, and }(+) \text {-sativene }\end{array}$ & Paul and Park (2013) \\
\hline & C. sphaerospermum & Plant-growth promoting & Mixture of FVOCs & Li et al. (2019) \\
\hline & $\begin{array}{l}\text { Cladosporium sp. and } \\
\text { Ampelomyces sp. }\end{array}$ & $\begin{array}{l}\text { Plant-growth promoting and } \\
\text { plant immunity induction }\end{array}$ & Methyl benzoate & Naznin et al. (2014) \\
\hline & Talaromyces sp. & $\begin{array}{l}\text { Plant-growth promoting and } \\
\text { plant immunity induction }\end{array}$ & $\beta$-Caryo-phyllene & Yamagiwa et al. (2011) \\
\hline & $\begin{array}{l}\text { Verticillium bulbillo- } \\
\text { sum }\end{array}$ & Antifungal & Mixture of FVOCs & $\begin{array}{l}\text { Nicolotti and Varese } \\
\text { (1996) }\end{array}$ \\
\hline & $\begin{array}{l}\text { Saccharomyces cere- } \\
\text { visiae }\end{array}$ & Antifungal & $\begin{array}{l}\text { Ethanol, 3-methyl-1-butanol, 2-methyl- } \\
\text { 1-butanol, ethyl acetate, phenylethyl } \\
\text { alcohol, ethyl octanoate }\end{array}$ & Fialho et al. (2010) \\
\hline \multirow[t]{6}{*}{ Pathogenic } & Fusarium culmorum & $\begin{array}{l}\text { Induction of growth, motility, } \\
\text { and secondary metabolism of } \\
\text { bacteria }\end{array}$ & $\beta$-Phellandrene and other terpens & $\begin{array}{l}\text { Schmidt et al. (2016), } \\
\text { Schmidt et al. (2017) }\end{array}$ \\
\hline & Fusarium fujikuroi & Anti-microbial & Gibepyrones B-F & Barrero et al. (1993) \\
\hline & Fusarium oxysporum & Plant-growth promotion & Mixture of terpens & Bitas et al. (2015) \\
\hline & Alternaria alternate & $\begin{array}{l}\text { Increase the growth, chloro- } \\
\text { phyll content, and increase } \\
\text { photosynthesis capacity }\end{array}$ & $\begin{array}{l}\text { 2-Methyl-1-propanol, 2-pentanone, } \\
\text { 2-methyl-1 butanol, 1-octen-3-ol, } \\
\text { 3-octanone }\end{array}$ & Ameztoy et al. (2019) \\
\hline & Rhizoctonia solani & $\begin{array}{l}\text { Increase the growth and } \\
\text { accelerate the development } \\
\text { of Arabidopsis thaliana }\end{array}$ & Unknown & Cordovez et al. (2017) \\
\hline & Aspergillus flavus & Antimicrobial & $\begin{array}{l}\text { 2,4,4-Trimethyl-2-pentene, 2-methyl- } \\
\text { butane, 1-methoxy-1-buten-3-yne }\end{array}$ & Spraker et al. (2014) \\
\hline \multirow[t]{2}{*}{ Symbiotic } & Laccaria bicolor & $\begin{array}{l}\text { Stimulation of lateral root } \\
\text { formation }\end{array}$ & (-)-thujopsene & Ditengou et al. (2015) \\
\hline & Tuber species & Phytotoxic activity & $\begin{array}{l}\text { 1-Octen-3-ol, 2-phenylethanol, 3-meth- } \\
\text { yl-1-butanol, 1-hexanol, 3-octanol, } \\
\text { 3-octanone, and trans-2-octenal }\end{array}$ & Splivallo et al. (2007) \\
\hline \multirow[t]{5}{*}{ Endophytic } & $\begin{array}{l}\text { Oxyporus latemar- } \\
\text { ginatus }\end{array}$ & Antifungal & 5-Pentyl-2-furaldehyde & Lee et al. (2009) \\
\hline & Muscodor albus & Antifungal & $\begin{array}{l}\text { 3-Methyl-acetate, alcohol, 2-methyl- } \\
\text { 1-butanol, and isobutyric acid }\end{array}$ & $\begin{array}{l}\text { Strobel (2006), } \\
\text { Mercier et al. (2007) }\end{array}$ \\
\hline & Xylaria sp. & Phytotoxic activity & $\begin{array}{l}\text { 2-Methyl-1-propanol and 2- methyl- } \\
\text { 1-butanol }\end{array}$ & Sánchez-Ortiz et al. (2016) \\
\hline & $\begin{array}{l}\text { Hypoxylon antho- } \\
\text { chroum }\end{array}$ & $\begin{array}{l}\text { Antifungal and phytotoxic } \\
\text { activity }\end{array}$ & Phenylethyl alcohol, eucalyptol & Ulloa-Benítez et al. (2016) \\
\hline & Trichoderma gamsii & Anti-microbial & $\begin{array}{l}\text { Dimethyl disulfide, dibenzofuran, } \\
\text { methanethiol }\end{array}$ & Chen et al. (2016) \\
\hline
\end{tabular}

FVOC, fungal volatile compound. 
A

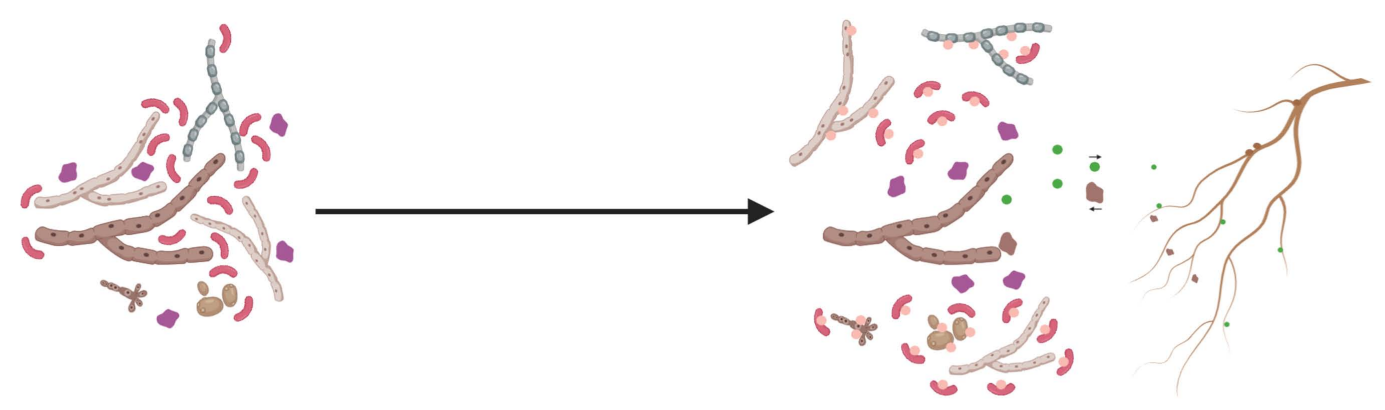

B

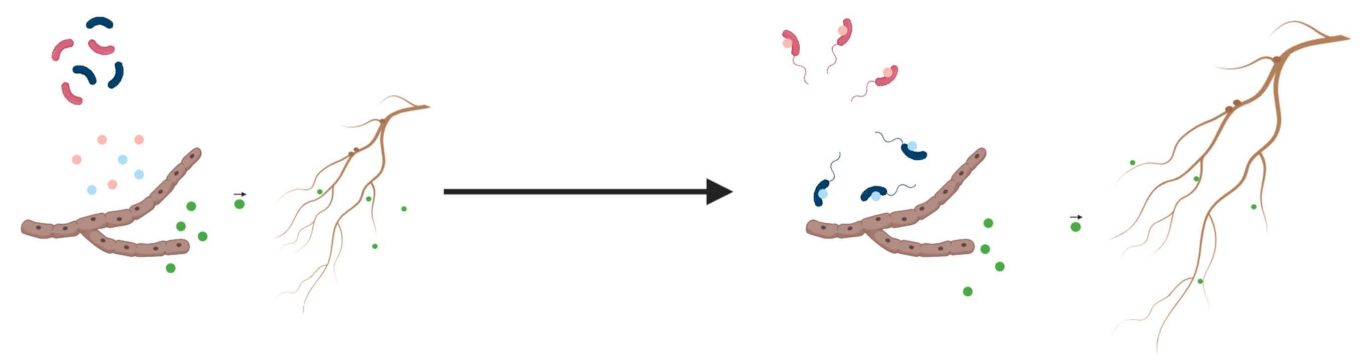

C

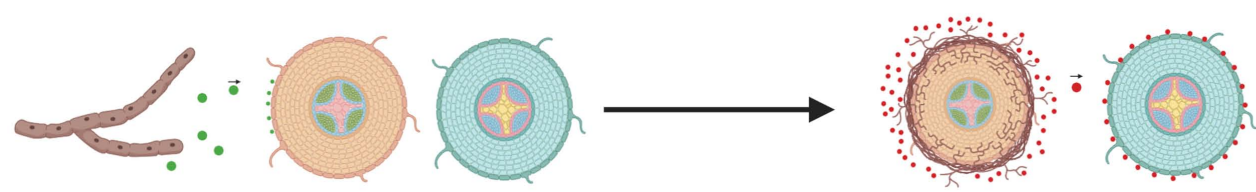

D
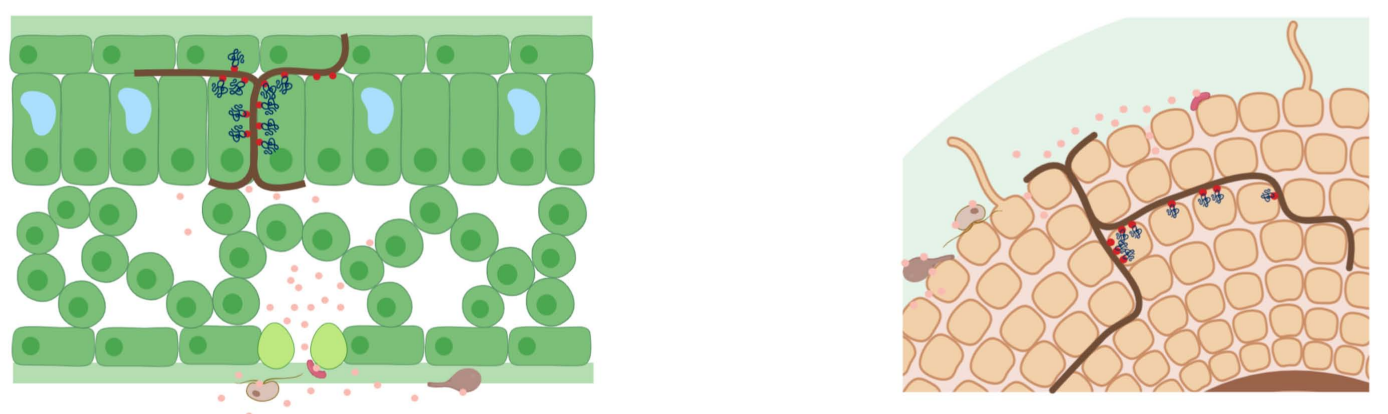

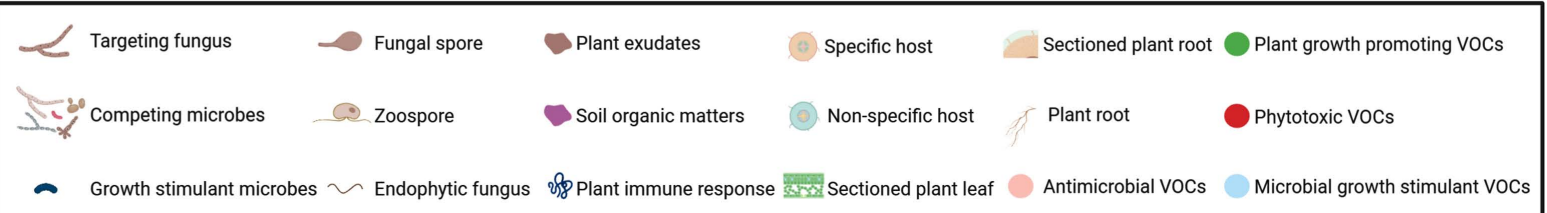

Fig. 1. Role of fungal volatile compounds (FVOCs) in orchestrating different lifestyles of filamentous fungi. In every lifestyle, filamentous fungi produce at least two biologically different classes of FVOCs. Saprophytic fungi produce a bouquet of FVOCs to maximize the nutrient availability around the hyphae by either eliminating their competitors or supporting the plant growth (A). Pathogens pave their way to the host plants by producing a bouquet of volatile info-chemicals that attract or repel beneficial or harmful microorganisms, respectively, and/or predispose the plant growth to the infection process (B). Mutualistic fungi initially produce volatile info-chemicals that strengthen the host recognition. After colonization is successfully established, they produce phytotoxic FVOCs that reconstruct the vegetation structure around the host (C). Leaf (left panel) and root (right panel) endophytic fungi protect their tiny niche inside and outside the plant tissues by producing a mixture of FVOCs, some of which act as antimicrobial and others act as phytotoxic simultaneously (D). VOCs, volatile compounds. 
matter, but attack living host cells when host are available around their environment (facultative parasites), and some live most of the life cycle within the living host cells and shortly live saprophytically (facultative saprophytes) (Agrios, 2005). Unlike FVOCs of saprophytes, FVOCs produced by pathogens show low chemical diversity and most likely act as info-chemicals, i.e., chemical stimuli, to attract or repel interacting organisms. Such property of FVOCs as info-chemicals can be exemplified by the study demonstrating that the terpenic volatiles of the common root-rot causing fungus, Fusarium culmorum, can increase the motility and the growth of Serratia plymuthica. Proteomic analysis identified the methyl-accepting chemotaxis protein IV, which acts as a chemotactic-signal sensor that detects attractants and promotes bacterial movement, added to other transcriptomic observations such as multidrug tolerance, energy metabolism, and cell growth. Last and not the least, it was found that the volatiles trigger Serratia plymuthica to produce an unusual terpene sodorifen. This metabolic observation had supported with the transcriptomic data, which revealed the up-regulation of genes related to secondary metabolism production (Schmidt et al., 2016, 2017). Furthermore, the pathogen of rice bakanae disease, Fusarium fujikuroi, produces a pyrones-type FVOCs, called gibepyrones. These compounds exhibited antimicrobial activities against several bacterial and yeast species, but no further investigation had been done afterwards (Barrero et al., 1993). During interaction with host plants, it seems that some FVOCs of pathogens work as a stimulant to the plant growth. This was evidenced by the studies regarding the influence of FVOCs produced by the pathogens on the growth of the model plant Arabidopsis thaliana under normal or stressful conditions. In one study, the authors showed that volatiles of the fungal root pathogen Rhizoctonia solani enhance growth and accelerate the development of $A$. thaliana. However, the molecular mechanism of growth promotion has yet to be elucidated (Cordovez et al., 2017). In other examples, FVOCs of the wilt causing pathogens, Verticillium dahliae and $F$. oxysporum improved the root growth of $A$. thaliana and tobacco plants by the induction of auxin signaling (Bitas et al., 2015; Li and Kang, 2018). In case of foliar pathogens, some FVOCs appear to improve not only growth but also the photosynthetic capacity of the host plants. Such effect of FVOCs were observed in A. thaliana seedlings treated with FVOCs of the leaf spot pathogen, Alternaria alternate. Subcellular analysis revealed that NADPH-dependent thioredoxin reductase $\mathrm{C}$ is the key mediator of plant response to FVOCs through mechanisms involving changes in global thiol redox proteome that affect photosynthesis (Ameztoy et al.,
2019). List of other pathogens producing FVOCs with different biological activities is provided in Table 1. Based on the aforementioned actions of pathogens' FVOCs, we can probably infer that pathogens emit FVOCs to manipulate other organisms from distance before approaching to the infection site of the host and causing disease. It might be that the pathogens give off FVOCs to other microorganisms so that they attract particular microbes, while repelling antagonistic or non-beneficial microbes. Alternatively, the FVOCs might predispose the hosts to pathogen infection by manipulating host cells to allocate more energy and resources for growth than defense (Fig. 1B).

Mutualistic fungi. Mutualistic fungi are reminiscent of pathogenic fungi in that they also live on other living organisms. Unlike pathogens, however, mutualism benefits all sides: fungi obtain their essential nutrients, such as carbohydrates and proteins, fully prepared by the host organisms, and in return, they have to pay back to the host, mostly by providing sufficient water and minerals that are not readily accessible to the host (Agrios, 2005). Mutualistic fungi encompass phylogenetically discrete groups. Archetypal examples of mutualism include two groups of fungi: one that associates with algal cells and another that associates with plant roots. The former association relationship is called lichen, while that of the latter called mycorrhizae. Mycorrhizal fungi (MF) are also divided into two groups, depending on the way they colonize the plant roots. One wraps the out surface of plant roots and called "ecto" mycorrhizal fungi (EMF) accordingly, whereas the other colonizes the roots subcellularly and therefore, called endo or arbuscular mycorrhizal fungi (AMF) (Vashishta et al., 2016). The release of specific FVOCs is thought to be the main player establishing these delicate relationships, leading to extensive studies on FVOCs particularly from MF due to their importance in the plant growth. In both types of mycorrhizal fungi, it is found that FVOCs play roles in root development but are not involved in host recognition. FVOCs of the both EMF and AMF have been found to cause lateral root development and root hairs growth of their respective hosts (Ditengou et al., 2015; Sun et al., 2015). To date, the major FVOCs produced by MF, which play roles in manipulating the structure of the plant root, are sesquiterpenes (Ditengou et al., 2015). However, they were found to influence the roots of the non-host plant, $A$. thaliana as well, while only exudates of AMF trigger the roots of the respective hosts (Sun et al., 2015). These FVOCs are likely to exert their effects potentially through mechanisms involving reactive oxygen species, ethylene and auxin, which associated with polarity in cell growth, lateral root 
development, and apical root growth, respectively (Felten et al., 2009; Foreman et al., 2003; Overvoorde et al., 2010; Saini et al., 2013; Splivallo et al., 2009). After colonization, mycorrhizal fungi, however, go about giving off FVOCs, but in this stage, the flying FVOCs is not in favor of the plant growth as they are in the early stage of the relationship establishment. For instance, some species of the ectomycorrhizal truffles, such as Tuber melanosporum, $T$. indicum, and T. borchii, produce FVOCs that have been proven to exert negative effects on different growth stages of $A$. thaliana. The compounds that have been involved in this phytotoxic response are 1-octen-3-ol, 2-phenylethanol, 3-methyl-1-butanol, 1-hexanol, 3-octanol, 3-octanone, and trans-2-octenal (Splivallo et al., 2007). Information about FVOCs of symbiotic fungi are summarized in Table1. From these observations, it was proposed that the mutualistic fungi initially use information-carrying FVOCs to facilitate the host recognition process, which is mainly orchestrated by the fungal exudates. Once fungi succeed in colonizing the host, however, it switches to producing FVOCs of phytotoxic effect (Fig. 1C). Such FVOCs probably contribute to killing off the surrounding plants that potentially compete with the host plant, thereby reformulating the vegetation structure (Splivallo et al., 2009; Streiblová et al., 2012).

Endophytic fungi. Endophytic fungi refer to the fungi that live within the plant tissues without showing any sign of harm (Rodriguez et al., 2009). Although they had been discovered in the 19th century, they had been taken a huge interest from microbiologists, following the discovery when it was found that an endophytic fungus is being associated with animal fescue toxicosis, a syndrome that influences cattle graze on pastures of the grass Festuca arundinacea (Schardl et al., 2004). Later on, a lot of works in agricultural biotechnology focused on endophytic fungi due to their secondary metabolites repertoire including volatile compounds (Kaddes et al., 2019). Most of investigated FVOCs from endophytes were shown to have antimicrobial activities against filamentous fungal pathogens and oomycetes, but some exhibited anti-bacterial activities (Gomes et al., 2018; Stinson et al., 2003b; Ulloa-Benítez et al., 2016). For example, FVOCs of Oxyporus latemarginatus, can inhibit the mycelial growth of many pathogenic fungi such as A. alternata, Colletotrichum gloeosporioides, Fusarium oxysporum, Botrytis cinerea, and $R$. solani. The antifungal activities are mainly attributed to the activity of 5-pentyl-2-furaldehyde (Lee et al., 2009). However, the anti-fungal mechanism of this compound has not been revealed yet. Despite the significant number of filamentous fungi isolated from plant endosphere compartment, species of Muscodor are particularly interesting, as all discovered species have been isolated from inside plant tissues. Besides, they harbor highly diverse FVOCs with strong anti-fungal activities (Ezra et al., 2004; Kudalkar et al., 2012; Mercier et al., 2007; Meshram et al., 2013; Suwannarach et al., 2016; Strobel et al., 2001). For example, FVOCs of M. albus were shown to inhibit the growth of $R$. solani and Phytophthora capsici and suppress the germination process of teliospores of Tilletia species (Mercier et al., 2007). Furthermore, in the field test, it could hamper the growth of pathogens such Pythium ultimum and Aphanomyces cochlioides, hence improving the growth of sugar beets in infested soils in a process called myco-fumigation (Stinson et al., 2003a). For this reason, the strain was commercialized for plant protection by the industrial company AgraQuest (Strobel et al., 2005). The FVOCs bouquet of this promising species is comprised of isobutyl alcohol, 2-methyl-1-butanol, and isobutyric acid, which are thought to be responsible for the anti-fungal activity (Mercier et al., 2007). Data about other endophytes' FVOCs with antimicrobial activities are summarized in Table 1. Yet, the comprehensive antifungal mechanism is still unknown.

A few literatures have discussed phytotoxicity of FVOCs from endophytes with the hope of using it as bio-herbicides to combat the weeds. For example, Hypoxylon anthochroum and Xylaria sp. strain PB3f3 are found to negatively affect the growth of several plant species. FVOCs of $H$. anthochroum inhibit seed germination and seedling elongation and respiration of Amaranthus hypochondriacus, Panicum miliaceum, Trifolium pretense, and Medicago sativa. Those of Xylaria sp. strain PB3f3 inhibit root elongation of A. hypochondriacus and Solanum lycopersicum. It should be noted that in both cases, the significant phytotoxic effects were detected for FVOCs obtained from old cultures, which is accompanied by different volatile profiling from early stage growth. Furthermore, synthetic compounds of these FVOCs could show effect only in a concentration-dependent manner (Sánchez-Ortiz et al., 2016; Ulloa-Benítez et al., 2016). Nonetheless, no report has demonstrated the phytotoxicity of the endophytes FVOCs on the original host. From these lines of observations, it is tempting to speculate that endophytes might have evolved FVOCs to compete with other microbes for niches in endosphere, and/or to affect plant cells' activity (Fig. 1D).

\section{Role of Nature Settings in Making Sense of VOCs}

FVOCs are recognized as a tool that fungi use for communication and interactions with other organisms. However, 
all the data about FVOCs to date has been obtained under in-vitro condition using nutrient-rich media. Despite the promising achievements in the field using this approach, it might mislead our understanding about ecological functions of FVOCs, as this condition does not represent those of the natural niche. Kai and his coworkers authored a review paper discussing the different interaction systems between plant and bacteria aiming for estimating effects of bacteria VOCs on plant growth. In this work, the authors concluded that most of these systems lack fundamental features of the natural ecosystem, which might affect the production of VOCs qualitatively or quantitatively. Features that current in-vitro systems are lacking are interaction of the investigated microbes with biotic and abiotic components in the nature, such as other microbes, plants, their metabolites, and physicochemical properties of environment (Kai et al., 2016).

In order to address such discrepancies, researchers have established cultural methods that, to some extent, can mimic the natural ecosystem to reveal whether or not the microbial VOCs from laboratory-based systems are differ- ent from those from natural environments. For example, Garbeva and her colleagues tried to investigate the effect of rhizospheric bacterial VOCs on other nutrient-starved bacteria that live apart from rhizospheric area. They performed this by growing the producer bacteria, Collimonas pratensis, S. plymuthica, Paenibacillus sp., and Pedobacter sp., separately or in microbial mixture, in a petri-dish full of sand containing artificial root exudates, while the recipient bacterium, Pseudomonas fluorescens Pf0-1, was grown in the opposite side of the plate on nutrient-limited agar. On the contrary to initial prediction that VOCs of some of these isolates would hinder the growth of $P$. fluorescens, none of them inhibited the growth of the bacteria. VOCs of two strains, $C$. pratensis, $S$. plymuthica, rather promote the growth. Global transcriptomic analysis revealed that the VOCs of these two strains especially induced the expression of genes related to metabolism, motility, and secondary metabolism (Garbeva et al., 2014).

Unfortunately, literatures examining FVOCs in the context of natural settings are scarce. Some studies, however, point out potential caveats in conventional testing system.
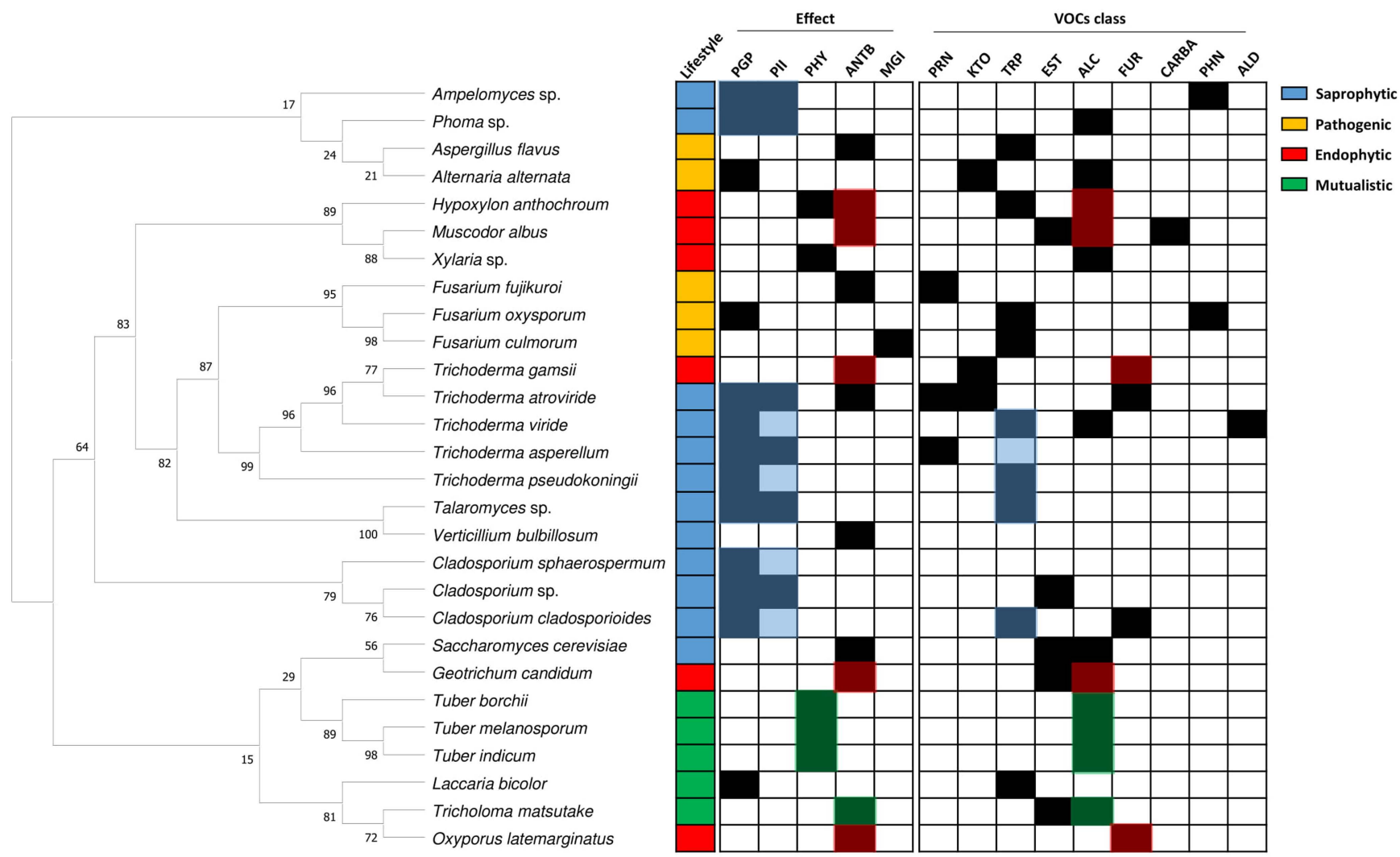

Fig. 2. Relationship between the fungal phylogeny, their lifestyles, their fungal volatile compounds and their biological activities. PGP, plant growth promoting; PII, plant immunity induction; PHY, phytotoxic; ANTB, antibiosis; MGI, microbial growth induction; PRN, pyrones; KTO, ketones; TRP, terpenes; EST, esters; ALC, alcohols; FUR, furans; CARBA, carboxylic acids; PHN, phenolics; ALD, aldehydes; VOCs, volatile compounds. 
For example, effect of the FVOCs emitted by F. culmorum on the growth and motility of $C$. pratensis Ter291 and $S$. plymuthica PRI-2C was studied by growing the fungus in two different media: water agar (WA) supplied with artificial root exudates and the nutrient-rich and common fungal lab media, potato dextrose agar (PDA). The results showed that volatiles produced from PDA-grown colonies affected the growth and the motility of those bacteria, while those of WA-grown colonies did not. In addition, more FVOCs were detected from the PDA-grown colonies than from WA-grown counterparts. Although the study took PDAemitted FVOCs for further investigation, it might not reveal the real ecological role of the FVOCs of this fungus. In addition, lack of the soil particle in the cultivation media might account for the poor FVOCs production in nutrientlimited media, WA (Schmidt et al., 2016). Overall, despite the advances made in the study of FVOCs, it is still not clear whether or not FVOCs isolated and studied in experimental settings are functional in the natural environments.

\section{Conclusion and Future Directions}

Our survey of literature regarding FVOCS showed that filamentous fungi produce a myriad of FVOCs with various biological activities, and such FVOCs have potentials for sustainable agricultural or even pharmaceutical applications (Kaddes et al., 2019; Morath et al., 2012). But they might also collectively help in shaping fungal lifestyles. Nonetheless, it is clear that majority of FVOC profiles have been obtained so far under laboratory settings, which may not be an accurate reflection of the naturally produced FVOCs. Efforts, therefore, should be made to overcome the limitation of testing systems and ultimately to establish systems that are close to natural settings. To accomplish this, many biotic and abiotic factors should be taken into account in the prospective testing systems.

In this review, we summarized all information we have collected in Fig. 2, in order to find a connection between fungal lifestyles and their FVOCs. As expected, there is no relationship between the fungal lifestyles and their phylogeny. Some correlations are, however, found between the fungal lifestyles, effects, and classes of FVOCs. For example, we observe from the collected data that most of FVOCs from saprophytes affect the plant growth and immunity, and possibly, terpenes are responsible for it. FVOCs from endophytes mostly have antimicrobial activities and this might be attributed to alcohols or furans. FVOCs from symbionts mostly act as antibiotics against organisms competing with the host, and possibly, alcohols are underlying this activity. Lastly, FVOCs from pathogens do not show any commonality in terms of the function or specific class, which is probably attributed to insufficiency of data for fungal pathogens. The observed correlations might serve as predictors that, given functions and classes of FVOCs detected in a particular fungus, might provide information about its lifestyle or vice versa. For example, if a fungus identified as a component of microbiome produce FVOCs of furans class, we can make prediction that it is likely to be an endophyte. However, more data should be forthcoming to verify such predictive value of volatile profiles. Furthermore, it should be noted that the signaling mechanisms triggered by FVOCs in the recipient organisms are still elusive. One reason for such knowledge gap is the fact that VOCs are structurally diverse, making identification and investigation of specific receptors or perception mechanisms a daunting task.

In conclusion, despite some breakthroughs of FVOC studies, the number of studies available for synthesis of wider perspective on FVOCs is seriously limited, pointing towards a dire need of research acceleration in this field. Such information would be essential for developing not only an understanding of evolution of fungal lifestyles but also application strategies of FVOCs for agriculture and ecosystem management.

\section{Acknowledgments}

This work was supported by a grant from the Rural Development Administration (PJ013178), and by Basic Science Research Program through the National Research Foundation of Korea (NRF) funded by the Ministry of Education, Science and Technology (NRF-2018R1A5A1023599).

\section{References}

Agrios, G. N. 2005. Plant pathology. 5th ed. Elsevier Academic Press, Amsterdam, The Netherlands. 952 pp.

Ameztoy, K., Baslam, M., Sánchez-López, Á. M., Muñoz, F. J., Bahaji, A., Almagro, G., García-Gómez, P., Baroja-Fernández, E., De Diego, N., Humplík, J. F., Ugena, L., Spíchal, L., Doležal, K., Kaneko, K., Mitsui, T., Cejudo, F. J. and Pozueta-Romero, J. 2019. Plant responses to fungal volatiles involve global posttranslational thiol redox proteome changes that affect photosynthesis. Plant Cell Environ. 42:2627-2644.

Baldrian, P. and Valásková, V. 2008. Degradation of cellulose by basidiomycetous fungi. FEMS Microbiol. Rev. 32:501-521.

Barrero, A. F., Oltra, J. E., Herrador, M. M., Cabrera, E., Sanchez, J. F., Quílez, J. F., Rojas, F. J. and Reyes, J. F. 1993. Gibepyrones: $\alpha$-pyrones from Gibberella fujikuroi. Tetrahedron 49:141-150.

Bitas, V., McCartney, N., Li, N., Demers, J., Kim, J. E., Kim, H. 
S., Brown, K. M. and Kang, S. 2015. Fusarium Oxysporum volatiles enhance plant growth via affecting auxin transport and signaling. Front. Microbiol. 6:1248.

Chen, J. L., Sun, S. Z., Miao, C. P., Wu, K., Chen, Y. W., Xu, L. H., Guan, H. L. and Zhao, L. X. 2016. Endophytic Trichoderma gamsii YIM PH30019: a promising biocontrol agent with hyperosmolar, mycoparasitism, and antagonistic activities of induced volatile organic compounds on root-rot pathogenic fungi of Panax notoginseng. J. Ginseng Res. 40:315-324.

Clegg, C. J. and Mackean, D. G. 2000. Advanced biology: principles and applications. 2nd ed. John Murray, London, UK. 720 pp.

Cordovez, V., Mommer, L., Moisan, K., Lucas-Barbosa, D., Pierik, R., Mumm, R., Carrion, V. J. and Raaijmakers, J. M. 2017. Plant phenotypic and transcriptional changes induced by volatiles from the fungal root pathogen Rhizoctonia solani. Front. Plant Sci. 8:1262.

Das, A., Lee, S.-H., Hyun, T. K., Kim, S.-W. and Kim, J.-Y. 2013. Plant volatiles as method of communication. Plant Biotechnol. Rep. 7:9-26.

De Vega, C., Herrera, C. M. and Dötterl, S. 2014. Floral volatiles play a key role in specialized ant pollination. Perspect. Plant Ecol. Evol. Syst. 16:32-42.

Dinis, M. J., Bezerra, R. M., Nunes, F., Dias, A. A., Guedes, C. V., Ferreira, L. M. M., Cone, J. W., Marques, G. S. M., Barros, A. R. N. and Rodrigues, M. A. M. 2009. Modification of wheat straw lignin by solid state fermentation with white-rot fungi. Bioresour. Technol. 100:4829-4835.

Ditengou, F. A., Müller, A., Rosenkranz, M., Felten, J., Lasok, H., van Doorn, M. M., Legué, V., Palme, K., Schnitzler, J.-P. and Polle, A. 2015. Volatile signalling by sesquiterpenes from ectomycorrhizal fungi reprogrammes root architecture. Nat. Commun. 6:6279.

Ezra, D., Hess, W. M. and Strobel, G. A. 2004. New endophytic isolates of Muscodor albus, a volatile-antibiotic-producing fungus. Microbiology 150:4023-4031.

Felten, J., Kohler, A., Morin, E., Bhalerao, R. P., Palme, K., Martin, F., Ditengou, F. A. and Legué, V. 2009. The ectomycorrhizal fungus Laccaria bicolor stimulates lateral root formation in poplar and Arabidopsis through auxin transport and signaling. Plant Physiol. 151:1991-2005.

Fialho, M. B., Toffano, L., Pedroso, M. P., Augusto, F. and Pascholati, S. F. 2010. Volatile organic compounds produced by Saccharomyces cerevisiae inhibit the in vitro development of Guignardia citricarpa, the causal agent of citrus black spot. World J. Microbiol. Biotechnol. 26:925-932.

Foreman, J., Demidchik, V., Bothwell, J. H. F., Mylona, P., Miedema, H., Torres, M. A., Linstead, P., Costa, S., Brownlee, C., Jones, J. D. G., Davies, J. M. and Dolan, L. 2003. Reactive oxygen species produced by NADPH oxidase regulate plant cell growth. Nature 422:442-446.

Fox, E. M. and Howlett, B. J. 2008. Secondary metabolism: regulation and role in fungal biology. Curr. Opin. Microbiol. $11: 481-487$.
Garbeva, P., Hordijk, C., Gerards, S. and de Boer, W. 2014. Volatile-mediated interactions between phylogenetically different soil bacteria. Front. Microbiol. 5:289.

Garnica-Vergara, A., Barrera-Ortiz, S., Muñoz-Parra, E., RayaGonzález, J., Méndez-Bravo, A., Macías-Rodríguez, L., RuizHerrera, L. F. and López-Bucio, J. 2016. The volatile 6-pentyl-2H-pyran-2-one from Trichoderma atroviride regulates Arabidopsis thaliana root morphogenesis via auxin signaling and ETHYLENE INSENSITIVE 2 functioning. New Phytol. 209:1496-1512.

Gomes, A. A., Pinho, D. B., Cardeal, Z. L., Menezes, H. C., De Queiroz, M. V. and Pereira, O. L. 2018. Simplicillium coffeanum, a new endophytic species from Brazilian coffee plants, emitting antimicrobial volatiles. Phytotaxa 333:188-198.

Hobbie, E. A., Macko, S. A. and Shugart, H. H. 1999. Insights into nitrogen and carbon dynamics of ectomycorrhizal and saprotrophic fungi from isotopic evidence. Oecologia 118:353360.

Holopainen, J. K. and Blande, J. D. 2012. Molecular plant volatile communication. In: Sensing in nature, ed. by C. LópezLarrea, pp. 17-31. Springer-Verlag, New York, USA.

Hung, R., Lee, S. and Bennett, J. W. 2013. Arabidopsis thaliana as a model system for testing the effect of Trichoderma volatile organic compounds. Fungal Ecol. 6:19-26.

Hung, R., Lee, S. and Bennett, J. W. 2015. Fungal volatile organic compounds and their role in ecosystems. Appl. Microbiol. Biotechnol. 99:3395-3405.

Jalali, F., Zafari, D. and Salari, H. 2017. Volatile organic compounds of some Trichoderma spp. increase growth and induce salt tolerance in Arabidopsis thaliana. Fungal Ecol. 29:67-75.

Kaddes, A., Fauconnier, M. L., Sassi, K., Nasraoui, B. and Jijakli, M. H. 2019. Endophytic fungal volatile compounds as solution for sustainable agriculture. Molecules 24:1065.

Kai, M., Effmert, U. and Piechulla, B. 2016. Bacterial-plantinteractions: approaches to unravel the biological function of bacterial volatiles in the rhizosphere. Front. Microbiol. 7:108.

Kanchiswamy, C. N., Malnoy, M. and Maffei, M. E. 2015. Chemical diversity of microbial volatiles and their potential for plant growth and productivity. Front. Plant Sci. 6:151.

Kottb, M., Gigolashvili, T., Großkinsky, D. K. and Piechulla, B. 2015. Trichoderma volatiles effecting Arabidopsis: from inhibition to protection against phytopathogenic fungi. Front. Microbiol. 6:995.

Kudalkar, P., Strobel, G., Riyaz-Ul-Hassan, S., Geary, B. and Sears, J. 2012. Muscodor sutura, a novel endophytic fungus with volatile antibiotic activities. Mycoscience 53:319-325.

Lee, S. O., Kim, H. Y., Choi, G. J., Lee, H. B., Jang, K. S., Choi, Y. H. and Kim, J.-C. 2009. Mycofumigation with Oxyporus latemarginatus EF069 for control of postharvest apple decay and Rhizoctonia root rot on moth orchid. J. Appl. Microbiol. 106:1213-1219.

Lee, S., Yap, M., Behringer, G., Hung, R. and Bennett, J. W. 2016. Volatile organic compounds emitted by Trichoderma 
species mediate plant growth. Fungal Biol. Biotechnol. 3:7.

Li, N. and Kang, S. 2018. Do volatile compounds produced by Fusarium oxysporum and Verticillium dahliae affect stress tolerance in plants? Mycology 9:166-175.

Li, Z. T., Janisiewicz, W. J., Liu, Z., Callahan, A. M., Evans, B. E., Jurick, W. M. and Dardick, C. 2019. Exposure in vitro to an environmentally isolated strain TC09 of Cladosporium sphaerospermum triggers plant growth promotion, early flowering, and fruit yield increase. Front. Plant Sci. 9:1959.

McMillan, J. D. and Boynton, B. L. 1994. Arbinose utilization by xylose-fermenting yeasts and fungi. Appl. Biochem. Biotech. 45:569-584.

Mercier, J., Jiménez-Santamaría, J. I. and Tamez-Guerra, P. 2007. Development of the volatile-producing fungus Muscodor albus worapong, Strobel, and Hess as a novel antimicrobial biofumigant. Rev. Mex. Fitopatol. 25:173-179.

Meshram, V., Kapoor, N. and Saxena, S. 2013. Muscodor kashayum sp. nov.: a new volatile anti-microbial producing endophytic fungus. Mycology 4:196-204.

Mishra, P., Singh, S. K. and Nilegaonkar, S. S. 2011. Extracellular chitinase production by some members of the saprophytic Entomophthorales group. Mycoscience 52:271-277.

Morath, S. U., Hung, R. and Bennett, J. W. 2012. Fungal volatile organic compounds: a review with emphasis on their biotechnological potential. Fungal Biol. Rev. 26:73-83.

Naznin, H. A., Kimura, M., Miyazawa, M. and Hyakumachi, M. 2013. Analysis of volatile organic compounds emitted by plant growth-promoting fungus Phoma sp. GS8-3 for growth promotion effects on tobacco. Microbes Environ. 28:42-49.

Naznin, H. A., Kiyohara, D., Kimura, M., Miyazawa, M., Shimizu, M. and Hyakumachi, M. 2014. Systemic resistance induced by volatile organic compounds emitted by plant growth-promoting fungi in Arabidopsis thaliana. PLoS ONE 9:e86882.

Nicolotti, G. and Varese, G. C.1996. Screening of antagonistic fungi against air-borne infection by Heterobasidion annosum on Norway spruce. Forest Ecol. Manage. 88:249-257.

Overvoorde, P., Fukaki, H. and Beeckman, T. 2010. Auxin control of root development. Cold Spring Harb. Perspect. Biol. 2:a001537.

Paul, D. and Park, K. S. 2013. Identification of volatiles produced by Cladosporium cladosporioides CL-1, a fungal biocontrol agent that promotes plant growth. Sensors 13:13969-13977.

Pichersky, E., Noel, J. P. and Dudareva, N. 2006. Biosynthesis of plant volatiles: nature's diversity and ingenuity. Science 311:808-811.

Richard, F.-J. and Hunt, J. H. 2013. Intracolony chemical communication in social insects. Insect. Soc. 60:275-291.

Rodriguez, R. J., White, J. F. Jr., Arnold, A. E. and Redman, R. S. 2009. Fungal endophytes: diversity and functional roles. New Phytol. 182:314-330.

Ryu, C.-M., Farag, M. A., Hu, C.-H., Reddy, M. S., Kloepper, J. W. and Paré, P. W. 2004. Bacterial volatiles induce systemic resistance in Arabidopsis. Plant Physiol. 134:1017-1026.
Saini, S., Sharma, I., Kaur, N. and Pati, P. K. 2013. Auxin: a master regulator in plant root development. Plant Cell Rep. 32:741-757.

Sánchez-Ortiz, B. L., Sánchez-Fernández, R. E., Duarte, G., Lappe-Oliveras, P. and Macías-Rubalcava, M. L. 2016. Antifungal, anti-oomycete and phytotoxic effects of volatile organic compounds from the endophytic fungus Xylaria sp. strain PB3f3 isolated from Haematoxylon brasiletto. J. Appl. Microbiol.120:1313-1325.

Schalchli, H., Tortella, G. R., Rubilar, O., Parra, L., Hormazabal, E. and Quiroz, A. 2016. Fungal volatiles: an environmentally friendly tool to control pathogenic microorganisms in plants. Crit. Rev. Biotechnol. 36:144-152.

Schardl, C. L., Leuchtmann, A. and Spiering, M. J. 2004. Symbioses of grasses with seedborne fungal endophytes. Annu. Rev. Plant Biol. 55:315-340.

Schausberger, P., Peneder, S., Jürschik, S. and Hoffmann, D. 2012. Mycorrhiza changes plant volatiles to attract spider mite enemies. Funct. Ecol. 26:441-449.

Schmidt, R., Cordovez, V., de Boer, W., Raaijmakers, J. and Garbeva, P. 2015. Volatile affairs in microbial interactions. ISME J. 9:2329-2335.

Schmidt, R., Etalo, D. W., de Jager, V., Gerards, S., Zweers, H., de Boer, W. and Garbeva, P. 2016. Microbial small talk: volatiles in fungal-bacterial interactions. Front. Microbiol. 6:1495.

Schmidt, R., Jager, V., Zühlke, D., Wolff, C., Bernhardt, J., Cankar, K., Beekwilder, J., Ijcken, W. V., Sleutels, F., Boer, W., Riedel, K. and Garbeva, P. 2017. Fungal volatile compounds induce production of the secondary metabolite Sodorifen in Serratia plymuthica PRI-2C. Sci. Rep. 7:862.

Splivallo, R., Fischer, U., Göbel, C., Feussner, I. and Karlovsky, P. 2009. Truffles regulate plant root morphogenesis via the production of auxin and ethylene. Plant Physiol. 150:2018-2029.

Splivallo, R., Novero, M., Bertea, C. M., Bossi, S. and Bonfante, P. 2007. Truffle volatiles inhibit growth and induce an oxidative burst in Arabidopsis thaliana. New Phytol. 175:417-424.

Spraker, J. E., Jewell, K., Roze, L. V., Scherf, J., Ndagano, D., Beaudry, R., Linz, J. E., Allen, C. and Keller, N. P. 2014. A volatile relationship: profiling an inter-kingdom dialogue between two plant pathogens, Ralstonia Solanacearum and Aspergillus Flavus. J. Chem. Ecol. 40:502-513.

Stinson, A. M., Zidack, N. K., Strobel, G. A. and Jacobsen, B. J. 2003a. Mycofumigation with Muscodor albus and Muscodor roseus for control of seedling diseases of sugar beet and Verticillium wilt of eggplant. Plant Dis. 87:1349-1354.

Stinson, M., Ezra, D., Hess, W. M., Sears, J. and Strobel, G. 2003b. An endophytic Gliocladium sp. of Eucryphia cordifolia producing selective volatile antimicrobial compounds. Plant Sci.165:913-922.

Stoppacher, N., Kluger, B., Zeilinger, S., Krska, R. and Schuhmacher, R. 2010. Identification and profiling of volatile metabolites of the biocontrol fungus Trichoderma atroviride by HS-SPME-GC-MS. J. Microbiol. Methods 81:187-193.

Streiblová, E., Gryndlerová, H. and Gryndler, M. 2012. Truffle 
brûlé: an efficient fungal life strategy. FEMS Microbiol. Ecol. 80:1-8.

Strobel, G. 2006. Harnessing endophytes for industrial microbiology. Curr. Opin. Microbiol. 9:240-244.

Strobel, G. A., Dirkse, E., Sears, J. and Markworth, C. 2001. Volatile antimicrobials from Muscodor albus, a novel endophytic fungus. Microbiology 147:2943-2950.

Strobel, G., Manker, D. C. and Mercier, J. 2005. Endophytic fungi and methods of use. U.S. Patent No. US 6,911,338 B2. U.S. Patent and Trademark Office, Washington, DC, USA.

Sun, X.-G., Bonfante, P. and Tang, M. 2015. Effect of volatiles versus exudates released by germinating spores of Gigaspora margarita on lateral root formation. Plant Physiol. Biochem. 97:1-10.

Suwannarach, N., Bussaban, B., Nuangmek, W., Pithakpol, W., Jirawattanakul, B., Matsui, K. and Lumyong, S. 2016. Evaluation of Muscodor suthepensis strain CMU-Cib462 as a postharvest biofumigant for tangerine fruit rot caused by Penicillium digitatum. J. Sci. Food Agric. 96:339-345.

Ueda, H., Kikuta, Y. and Matsuda, K. 2012. Plant communication: mediated by individual or blended VOCs? Plant Signal. Behav. 7:222-226.

Ulloa-Benítez, Á., Medina-Romero, Y. M., Sánchez-Fernández,
R. E., Lappe-Oliveras, P., Roque-Flores, G., Duarte Lisci, G., Herrera Suárez, T. and Macías-Rubalcava, M. L. 2016. Phytotoxic and antimicrobial activity of volatile and semivolatile organic compounds from the endophyte Hypoxylon anthochroum strain Blaci isolated from Bursera lancifolia (Burseraceae). J. Appl. Microbiol.121:380-400.

Vashishta, B. R., Sinha, A. K. and Kumar, A. 2016. Botany for degree students: fungi. Rev. ed. S. Chand and Company, New Delhi, India. 794 pp.

Vespermann, A., Kai, M. and Piechulla, B. 2007. Rhizobacterial volatiles affect the growth of fungi and Arabidopsis thaliana. Appl. Environ. Microbiol. 73:5639-5641.

Wenke, K., Kai, M. and Piechulla, B. 2010. Belowground volatiles facilitate interactions between plant roots and soil organisms. Planta 231:499-506.

Woo, S. L., Ruocco, M., Vinale, F., Nigro, M., Marra, R., Lombardi, N., Pascale, A., Lanzuise, S., Manganiello, G. and Lorito, M. 2014. Trichoderma-based products and their widespread use in agriculture. Open Mycol. J. 8:71-126.

Yamagiwa, Y., Inagaki, Y., Ichinose, Y., Toyoda, K., Hyakumachi, M. and Shiraishi, T. 2011. Talaromyces wortmannii FS2 emits $\beta$-caryphyllene, which promotes plant growth and induces resistance. J. Gen. Plant Pathol. 77:336-341. 